\title{
IETS OVER DE HELLEN DER BUDDHISTEN.
}

\author{
DOoR H. KERN.
}

Volgens een algemeen bij de Buddhisten heerschende voorstelling zijn er 8 voorname hellen (naraka ${ }^{1}$, niraya). Men vindt de namen opgegeven in Jātaka V, 266, nl.:

Samjīivo, Kālasutto ca Samighāto dve ca Roruve |

athāparo Mahāvīci Tapano ca Patāpano ||

Hiermeê komt overeen de opsomming in Mahāvastu I, 9 en III, 454 :

Samijīvaṃ Kālasūtram ca Samighātam [ca] dvau ca Roravau |

athāparā Mahāvīcī Tapano ca Pratāpano ||

Eenige namen zijn licht te begrijpen. Zoo beteekent Tapano «brandend" en tevens "pijnigend"; Pratāpana hetzelfde in sterkeren graad. Roruva, Rorava (ook Raurava, o.a. Manu IV, 85 ) beteekent zoo iets als "voortdurend gebrul» of "brullend" 2 Avīci houd ik voor een bijvorm van avācis "naar beneden gelegen, vrouwelijk van avã̃̃, gevormd als udīcī van uda ñc. Minder duidelijk is kālasutta. Dit komt voor in Milinda-P. 413, en Jāt. II, 405, alsook 19 (met var. 1. kāla) als benaming van een timmermansgereedschap. Daar $k \bar{a} ! ̣$, zwart, is, schijnt kā la sutta eigenlijk "een zwarte maatlijn» te beteekenen, doch de toepassing van zoo iets op een hel is mij duister. In 't Skr. kālas ūtra laat zich niet uitmaken of met $k \bar{a} l a$ bedoeld is "zwart» dan wel «tijd, dood». In 't Pet. Wdb. wordt het vertaald met "der Faden der Zeit oder des Todes». In Mahābhārata XIII, 2479 wordt de naam omschreven met

\footnotetext{
$1 \mathrm{~N}$ araka beteekent eigenlijk een diep gat in den grond, bijv. Theragātha 896; afgrond, diepte, Jāt. IV, 269; VI, 308. Het woord is verwant met Gr.

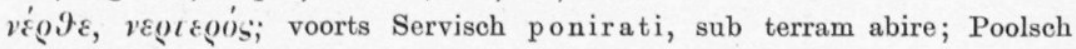
nora, höhlung unter der erde; Russisch nora, nor, loch; Litausch nerti, untertauchen, enz.

2 Volgens den Comm. op Jät. V, 271 wordt de eene Roruva nader aangeduid als Jāla-R., d.i. Vlammen-R.; de andere als Dhūma-R., d.i. RookRoruva.
} 
Kālasāhvaya, d.i. «Kāla genaamd», dat dubbelzinnig blijft. Even dubbelzinnig is Samghāta; het kan beteekenen "botsing, kamp, slag»; ook "afsluiting». Zonderling is de toepassing van den term samijīva (in Manu IV, 89 samjīvana), d.i. "'t leven opwekkend», op een hel.

Bij elke der groote hellen behooren 16 zoogenaamde Ussada's, Skr. Utsada's, een term dien ik met "Voorgeborchten" meen te mogen weergeven ${ }^{1}$. Dit staat uitgedrukt in de volgende strofe:

Icc-ete ațțha nirayā akkhātā duratikkamā |

àkiṇnā luddakammehi paccekā soḷassussadā \|

D.i. «Zoo zijn deze acht moeilijk te overkomen hellen genoemd, vol van boosdoeners. Ze hebben ieder 16 Ussada's».

Hiermede komt woordelijk overeen Mahāvastu t.a.p.

Ity ete așțau nirayā ākhyātā duratikramā |

àkīṇa raudrakarmebhiḥ ${ }^{3}$ pratyekā șoḍaçotsadā ||

Als men de $8 \times 16$ Ussada's of Voorgeborchten, dus 128 in getal, optelt bij de 8 voorname hellen, verkrijgt men alles te samen 136 hellen.

De overeenkomst van de beschrijving der hellen in 't Jātaka 4 met die in 't Mahāvastu is zóó groot, dat beide blijkbaar één en dezelfde overlevering tot grondslag hebben. Ten bewijze laat ik hier een gedeelte dier beschrijving volgen. In 't Jātaka leest men:

Kadariyātapanā ghorā accimantā mahabbhayā |

lomahamisanarūpā ca bhesmā pațibhayā dukhā ||

Catukkaṇṇ̄ā catudvārā vibhattā bhāgaso mitā |

ayopākārapariyantā ayasā pațikujjitā ||

Tesam ayomayā bhūmi jalitā tejasā yutā |

samantā yojanasatam phuṭā tiț̣̂hanti sabbadā \|

D.i. "Folterplaatsen voor de nijdigaards, gruwelijk, in vlammen gehuld, zeer vreeswekkend, en huiveringwekkend om te aanschouwen, schrikkelijk, vreeselijk, vol lijden. (Ze zijn) vierhoekig,

1 Ussada, Skr. Utsada, beteekent eigenlijk „uitstek" en ook „iets uitstekends." Bijv. Jāt. IV, 309: Catussadà் gāmavaram samiddha m, „een welvarend dorp met vier uitstekende eigenschappen." In Divyāvadāna 620 , rg. lezen wịj van een hoofddorp, dat aan een brahmaan door den koning gegeven was, dat het is: saptotsadam satṛnakāṣţhodakaṃ sadhanyabhogaị sahagatam.

${ }^{2}$ Mahāv. III, 454 heeft tegen de maat: ity ete așța mahānarakā.

s Mahāv. t.a.p. heeft raudrasatvehi.

- Alsook in Añguttara-Nikāya I, 141. 
met vier deuren, (zóó) afgedeeld dat elk deel (behoorlijk) is afgemeten; omgeven van ijzeren ringwallen en met ijzer overwelfd. Hun uit ijzer bestaande bodem is vlammend, van vuurgloed vervuld. Ze staan van alle kanten steeds honderd yojana's zichtbaar».

Hiermede komen in Mahāvastu III, 454 de volgende verzen, met eenige wijziging in de volgorde, overeen:

Catukarṇā ${ }^{1}$ caturdvārā vibhaktā bhāgaço mitā |

udgatā yojanaçatam samantā yojanaçatam $\|^{2}$

Atha ye narakaprakșiptā ${ }^{3}$ ayasā pratikubjitā |

teșām ayomayī bhūmi [pra]jvalitā tejasaminutā $\mid$ *

Kadaryatapanā ghorā ${ }^{\mathbf{5}}$ arcimanto durāsadā|

romaharṣanarūpā ca bhịṣmā pratibhayā dukhā ||

D.i. "(Ze zijn) vierhoekig, met vier deuren, (zóó) afgedeeld dat elk deel (behoorlijk) is afgemeten; hoog honderd Yojana's, en van alle kanten honderd Yojana's; omgeven van ijzeren ringwallen en met ijzer overwelfd. Hun uit ijzer bestaande bodem is vlammend, van vuurgloed vervuld. (Ze zijn) folterplaatsen voor nijdigaards, gruwelijk, in vlammen gehuld, moeielijk, te genaken, en huiveringwekkend te aanschouwen, schrikkelijk, vreeselijk, vol lijden».

In de aangetogen plaats uit Mahāvastu, waar een beschrijving van de hellen (narakavarnana) gegeven wordt, wordt ook verhaald dat de Sthavira Maudgalyāyana, een der twee voornaamste discipelen van den Buddha, een bezoek bracht aan de 8 groote hellen en de Utsada's. Hij placht dikwerf uitstapjes daarheen te maken. Opmerkelijk nu is het dat wij onder de door hem bezochte hellen eenige geheel andere namen aantreffen. Zoo vernemen wij dat lijders, uit de Samjīva verlost, te recht komen in de Kukkula; hieruit vervallen zij in de Kuṇapa, hieruit ontkomen, bereiken zij een plaats waar allerlei vogels met ijzeren snavels zijn; dan verder in 't Asipatravana (d.i. woud van boomen die zwaarden tot bladeren hebben); daaruit ontsnapt, komen zij aan de rivier Vaitaraṇi (de rivier der hel).

1 De tekst in Mahāv. I, t.a.p. heeft cat uḥ kalā, eenvoudig een schrijffout.

2 Niet wezenlijk verschillend heeft de parallelplaats samantāe chatay ojanam.

3 Corrupt voor ayaḥprākāraparikṣiptā, zooals de parallelplaats heeft.

4 De parallelplaats heeft tejasā yutā.

${ }^{5}$ De tekstuitgave Mahāv. I, 9 is foutief. Met behulp van de var. 1. is licht te herstellen: kadaryatapana ghorā. 
Bijna al deze namen komen ook elders voor, zoowel in Buddhistische als in Brahmanistische teksten. Bijv. Kukkula ${ }^{1}$ (eig. stroo-vuur) in Jāt. V, 143: Kukkulanāme nirayam i paccati, hij wordt gekookt in de Kukkula genaamde hel. Kuṇapa (eig. een rottend lijk) heb ik als naam van een hel in 't Pāli niet aangetroffen; ook niet in Brahmanistische geschriften. Asipatravana, Pāli asipattavana in Sutta-Nipāta 673; Asipatta-niraya Jāt. VI, 250. Vetaraṇī, de hellerivier, treft men meermalen aan, o. a. Jāt. VI, 250.

Men kan niet anders dan aannemen, dat al deze hellen die buiten 't kader der acht zoo te zeggen officieele groote hellen mitsgaders hun Utsada's vallen, toch in 't volksgeloof bekend waren en daarom door de Buddhistische verzamelaars en omwerkers van volksverhalen zijn overgenomen, zonder zich te bekommeren of die extrahellen met het stelsel van acht groote hellen strookten. Er komen trouwens in Buddhistische gewijde oorkonden ettelijke andere hellen voor. Zoo heb ik uit SuttaNip. 123, vg. opgeteekend de volgende namen ${ }^{2}$ van hellen: Ababa, Ațata, Nirabbuda, Paduma, Uppalaka. In Vimāna-Vatthu 52112 wordt gewag gemaakt van een hel Samsavaka; in Jāt. VI, 247 maken wij kennis met een Kākolaniraya, zoo genoemd naar de aldaar zijnde kākola's, raven; in het zelfde Jāt. 246 treffen wij ook de twee hellehonden Sabala en Sāma, d.i. Skr. Çabala en Çyāma, aan, ons welbekend als de twee wachthonden van Yama uit Atharva-Veda 8, 1, 9.

Wij hebben reeds gelegenheid gehad op te merken, dat een stelsel van 8 groote hellen algemeen Buddhistisch moet geweest zijn, aangezien het bestaan er van gewaarborgd is zoowel door een Pāli-tekst van de zich als rechtzinng beschouwende sekte als door een geschrift van de sekte der Lokottaravādins, een afdeeling der als schismatiek te boek staande Mahāsānghika's. $\mathrm{Nu}$ is er echter ook een stelsel van 16 groote hellen dat wij alleen kennen uit een werk van Noordelijke Hīnayānisten, namelijk het Avadāna-çataka ${ }^{3}$. Hierin vinden wij in Avadāna 7 , ge-

1 De mat eischt kukkūla of kuk qla. Doch beide vormen komen ook elders roor.

2 Eigenlijk namen van zeer hooge getallen. Ik veronderstel dat deze hellen zoo genoemd worden naar gelang van 't aantal eeuwen dat het verblijf in elke dier hellen duurt.

s Uitg. van Speyer, in Bibliotheca Buddhica, III. St. Petersburg, 1906. 
titeld Padma, p. 38, de volgende opsomming van 16 hellen, te weten: Samijīva, Kālasūtra, Samighāta, Raurava, Mahāraurava, Tapana, Pratāpana, Avīci, Arbuda, Nirarbuda, Ațața, Hahava, Huhuva, Utpala, Padma, Mahāpadma ${ }^{1}$. De eerste acht zijn heete hellen; de tweede, koude.

Men ziet dat de eerste acht hellen geheel dezelfde zijn als de vroeger behandelde, en wat de tweede rij betreft, vinden wij hier terug de namen Ațața, Nirarbuda, Padma en Utpala, die wij in Pāli-vorm boven reeds ontmoet hebben. Zonder twijfel waren ook de overige bij de Zuidelijke Buddhisten bekend.

Eindelijk valt nog te vermelden een bijzondere soort hel, geplaatst in de tusschenruimten der werelden; vandaar.de naam Lokantara-niraya, Jāt. VI, 247 ; of Lokantarika-niraya; Skr. Lokāntarika. Het is er helsch donker; 't licht van zon en maan dringt er niet door; alleen wanneer een Buddha verschijnt, wordt de duisternis verlicht door de stralen die van hem uitgaan ${ }^{2}$.

De Buddhistische monniken hebben de in hun geschriften geuite denkbeelden omtrent de hellen overgenomen uit het volksgeloof, niettegenstaande het heele begrip van hel en wat er meê samenhangt volstrekt in strijd is met een hoofdbeginsel van hun leerstelsel. Immers het Buddhisme loochent het bestaan van de ziel des menschen, en wat de levende niet bezit, kan na zijn dood niet voortbestaan. Wanneer een mensch sterft, gaan de vijf elementen waaruit hij is samengesteld, de Skandha's, Pāli Khanda's, te niet, en blijft alleen over het Karman (Pāli ka m ma m), d.i. de som van goede en kwade handelingen die de mensch bij zijn leven verricht heeft. Dit Karman heeft de kracht om een nieuw wezen te doen geboren worden, hetwelk beschouwd wordt als een herboorte van den overledene, wiens Karman zijn lot bepaalt. Tusschen iemands dood en wat als zijn herboorte beschouwd wordt, bestaat er niets dan 't Karman. Derhalve welke wezens kunnen dan vóór hun herboorte in de hel leven? Van de Lokantarika-hel wordt verkondigd dat ze de verblijfplaats is der Preta's, d.i. geesten der afgestorvenen. Het is wel de moeite waard te vernemen wat men van die Preta's weet

1 Vgl. de vertaling van Burnouf, Introd. 201. Dezelfde passage komt in A vad. meermalen voor.

` Zie o.a. Mahāvastu I, 229, en vgl. Spence Hardy, Manual, p. 28. 
te vertellen, zooals SPENCE HARdy ${ }^{1}$ mededeelt: "The Préta's inhabit the Lókántarika naraka. In appearance they are extremely attenuated, like a dṛy leaf. There are some prétas that haunt the places near which they had formerly lived as men; they are also found in the suburbs of cities, and in places where four ways meet». Deze voorstelling - het behoeft geen betoog, is door en door animistisch en overoud, maar wanhopig in strijd met het leerstuk dat er geen ziel is ${ }^{2}$. Niettemin is er een heel boek, getiteld Petavatthu, d.i. Pretageschiedenissen, dat onder de kanonieke geschriften een plaats heeft gevonden. In de verwarde voorstellingen aangaande de Preta's vindt men duidelijke sporen van de vereering van voorouders en afgestorven familieleden. Dit blijkt voldoende uit hetgeen CHILDERS ${ }^{3}$ zegt: "Many deceased relatives are Petas, and it is a highly meritorious act to place food and drink outside the house for the Petas to partake of when they revisit their former homes». Verder maakt dezelfde schrijver t. a. p. op: "It is to be observed that the Petas answer to both the Pitrs (voorouders) and Pretas (spoken) of Hinduism». Eigenlijke vooroudervereering als godsdienstige instelling bestaat niet in 't Buddhisme; dit is consequent. Intusschen kan men in eenige landen waar de vooroudervereering inheemsch is, zooals in China en Japan, spreken van een aanpassing daarvan aan 't Buddhistisch leerstelsel. Dit is echter een onderwerp dat buiten mijn bestek gelegen is.

Volgens de Buddhistische theorie behooren de Preta's, alsook de helbewoners, tot de klasse van wezens die met den term Opapatika, in 't Pāli, eenigszins afwijkend in 't Skr. Aupapāduka of Upapāduka, worden aangeduid. "An opapātika satta — om de uitdrukking van Childers ${ }^{4}$ te gebruiken — "means a

1 Manual, p. 47. Een uitvoeriger schildering van 't voorkomen van Preta's vindt men o.a. in Avadāna-çataka I, 242. Er zijn echter Preta's in gunstiger toestand verkeerende en Pretamaharddhika's, d.i. hoogedele Preta's geheeten; o.a. Avadānaç. I, 273.

2 Op een plaats in Milindo-Pañha wordt de leer verkondigd dat de wezens in de hellen door hun Karınan behouden blijven totdat zij herboren worden. Maar die veronderstelde wezens zijn krachtens de geloofsleer onbestaanbaar en kunnen dus niet behouden blijven.

3 Dict. 379. A vadānaç. No. 46 bevat het verhaal hoe Uttara een bezoek ontvangt van den geest zijner moeder, waarvan een andere versie in Petavatthu $\mathrm{II}, 10$.

4 Dict. 301.

Dl. 71. 
being reborn in another world without the intervention of parents, and therefore as it were uncaused, and seeming to appear by chance» ${ }^{1}$. Nu blijkt uit talrijke Preta-geschiedenissen dat zij niet den indruk maken van geboren te zijn, maar eenvoudig de geesten zijn van afgestorvenen, d.i. naar volmaakt animistische voorstelling, de onmiddellijke voortzetting van levende zielen. Van den boozen Devadatta wordt verteld dat hij als straf voor zijn euveldaden door de aarde verzwolgen werd en zoo ter helle voer. Hier is van een geboorte, van welken aard ook, geen sprake: Devadatta vaart in levenden lijve ter helle ${ }^{2}$. Volgens animistische begrippen is het voortleven van een mensch na den dood als geest begrijpelijk - ik zeg daarom nog niet: bestaanbaar - , maar die zienswijze veronderstelt 't bestaan van een ziel bij de levenden, iets hetgeen in strijd is met de Buddhistische leer. Het is te begrijpen dat de Buddhistische monniken getracht zullen hebben door een vernuftige theorie zekere onuitroeibare volksvoorstellingen in overeenstemming te brengen met hun eigen grondstellingen.

\section{$\mathrm{N}$ a s chrift.}

Nadat bovenstaand opstel geschreven werd, is onlangs in 't "Journal Asiatique», van Nov.-Dec. 1914, verschenen een artikel, getiteld: "L'enfer cambodgien d'après le Trai Phum (Tri Bhūmĩ) «les trois mondes», door M. RoEske». Daarin worden behalve de bovenvermelde hellen nog ettelijke andere plaatsen van foltering genoemd. Het belangrijkste in 't artikel is de nauwkeurige aanwijzing van de kategorieën van zondaars voor wie elke hel in 't bijzonder bestemd is. De bron van 't Cambodjasche geschrift is nog niet opgespoord.

1 Vgl. Spence Hardy, Manual 441, waar gezegd wordt dat zij geboren worden „bij apparitional birth."

2 In A vadānaç. I, 290 wordt verhaald dat zekere gierige rijkaard sterft en daarop (tasyopari) als een giftige slang geboren wordt. Iets verder wordt verteld, hoe hij, door den Buddha bekeerd, een hemeling wordt. 